Encontro Nacional de

Economia Industrial e Inovação

\title{
Fiscal Decentralization and Public R\&D Policy: a Cross-Country Analysis
}

Daniel Gama e Colombo ${ }^{\mathrm{a}}$ Jorge Martinez-Vazquez ${ }^{\mathrm{b}}$

\section{Área 6.2 - Políticas de Ciência, Tecnologia e Inovação}

\begin{abstract}
The objective of this paper is to examine whether the level of fiscal decentralization of a country is a relevant variable to explain public investment in innovation (measured as the share of research and development (R\&D) spending in total government budget) and the intensity of basic research within the public R\&D bundle. To assess the effects of decentralization, we present a theoretical model where a 'benevolent government' invests in R\&D aiming at maximizing net income available in the country (central government) or in the respective region (subnational government), states compete to attract capital investment, and R\&D results are subject to interregional knowledge spillovers. According to the model, decentralization leads to a lower share of basic research in government innovation spending. The impact on total $\mathrm{R} \& \mathrm{D}$ is ambiguous, although it tends to be negative. The conclusions of the model are tested through an empirical analysis using country aggregate data. Confirming the predictions of the model, we find evidence that expenditure decentralization leads to lower intensity of basic research within public R\&D, and that both types of decentralization negatively affect the size of innovation spending. Our findings suggest that deepening fiscal decentralization should be considered along with measures to compensate for innovation spending decrease, and that the central government should play a greater role in financing or carrying out basic research.
\end{abstract}

Key-Words: applied research; basic research; fiscal decentralization; innovation policy; knowledge spillovers.

JEL Codes: H23, H32, O38.

\section{Resumo}

O objetivo deste artigo é analisar se o nível de descentralização fiscal de um país é uma variável relevante para explicar o investimento público em inovação (medido como percentual do orçamento governamental dedicado a pesquisa e desenvolvimento - P\&D) e a proporção da pesquisa básica no gasto público em P\&D. É apresentado um modelo teórico no qual um governo interessado em promover o bem público investe em P\&D visando a maximizar a renda líquida disponível no país (no caso do governo central) ou na respectiva região (governo subnacional), estados competem para atrair capital, e os resultados de P\&D encontram-se sujeitos a transbordamentos de conhecimento inter-regionais. De acordo com o modelo, a descentralização leva a uma proporção menor de pesquisa básica no gasto público com inovação. O impacto no investimento total de P\&D é ambíguo, mas tende a ser negativo. As conclusões do modelo são testadas através de uma análise empírica utilizando dados agregados de diferentes países. Confirmando as previsões do modelo, essa análise evidencia que um nível mais elevado de descentralização de gastos gera uma menor intensidade de pesquisa básica na cesta de $\mathrm{P} \& \mathrm{D}$, e que tanto a descentralização de gastos quanto a de receitas afetam negativamente o gasto total com inovação. Os resultados sugerem que um aprofundamento da descentralização físcal de um país deve ser compensado com medidas para elevar o investimento público em P\&D, e que cabe ao governo central um papel maior no financiamento ou realização de pesquisa básica.

Palavras-chave: descentralização fiscal; pesquisa básica; pesquisa aplicada; política de inovação; transbordamentos de conhecimento.

Classificação JEL: H23, H32, O38.

\footnotetext{
a Instituto Nacional de Estudos e Pesquisas Educacionais Anísio Teixeira (Inep), Brasília (DF), Brazil. E-mail: daniel.colombo@inep.gov.br. At the time of this research, the author was a Ph.D. candidate at the School of Economics, Business and Accounting of the University of Sao Paulo, Sao Paulo (SP), Brazil.

${ }^{\mathrm{b}}$ International Center for Public Policy, Andrew Young School of Policy Studies, Georgia State University, Atlanta (GA), U.S. Email: jorgemartinez@gsu.edu.
} 


\section{Introduction}

As many countries continue to deepen their decentralization policies (OECD, 2016), science, technology and innovation (ST\&I) remain central in government strategies to promote growth and overcome societal challenges, especially in the aftermath of the 2008-2009 crisis (OECD, 2014). In this paper, we examine how these two policy trends interact, and, more specifically, what is the potential impact of fiscal decentralization on public spending on research and development (R\&D).

The fiscal federalism literature (summarized in section 2) has described and presented evidence of how decentralization levels (both on the revenue and expenditure side) affects government spending, assignment of functions, composition of budget and delivery of public policies. The main factors and economic forces that explain such effects are distinct preferences and circumstances among provinces (Oates, 1999), interjurisdictional spillovers (Hulten \& Schwab, 1997), factor mobility (Brennan \& Buchanan, 1980) and state competition (Zodrow \& Mieszkowski, 1986). However, up to this point such framework has not been used to analyze the case of ST\&I policy, and how distinct levels of decentralization change government incentives to foster innovation.

Similarly, to the best of our knowledge, the findings and lessons of these studies have not been carefully considered by the economics of innovation literature, whether to explain or to provide recommendations for the design of innovation policies and for the assignment of roles to different government levels. Yet, there is a strong case to suspect that fiscal decentralization should affect public spending on $\mathrm{R} \& \mathrm{D}$, mostly because of knowledge spillovers. As discussed in section 2, different empirical analyses have evidenced that a substantial part of $R \& D$ results is not internalized by the institution developing a new technology, and that such externalities spreads unevenly throughout different regions, with neighboring agents being in a better position to benefit from new knowledge flowing out of the research facility (Peri, 2005).

Considering this gap in the literature, this paper's aim is to present a first analysis and evidence of the link between fiscal decentralization and public spending on R\&D. At first, we identify a group of opposing forces that may affect this relationship. On one side, decentralized governance may lead to underprovision of public services characterized by large externalities that are not bounded to the subnational authority jurisdiction (Oates, 2008a) - such as ST\&I. On the other, fiscal competition between provinces may generate incentives for governments to increase innovation investments to attract new capital investment (Keen \& Marchand, 1997). The analysis becomes more complicated once we abandon a uniform view of R\&D and distinguish between basic and applied research ${ }^{1}$, with different levels of spillovers and potential to attract investment.

Two main questions are addressed herein: (a) whether there is any impact of fiscal decentralization on the share of R\&D in the government budget; and (b) whether it also affects the balance between basic research and applied research in the public R\&D bundle. To answer these questions, we first propose a theoretical model explaining the main economic forces that shape the government decision, and then we test its results through an empirical analysis using aggregate data on government expenditures.

This paper is structured as follows: in the second section we discuss the economic literature on fiscal decentralization and knowledge spillovers arising from R\&D investments. The third part presents the theoretical model and derives the propositions to be tested empirically. In the fourth section we describe the empirical analysis and discuss its results, along with potential policy implications. The fifth part closes the paper and suggests further research agenda on this subject.

\footnotetext{
${ }^{1}$ Throughout this paper, we use the standard definitions of innovation related concepts presented in the OECD Frascati Manual: innovation consists in the development of new information or increase in the stock of knowledge, and its application for economic purposes; both basic and applied research refer to an original investigation, but the first does not aim at any particular use, while the second is directed at a practical purpose or application; development, on the other hand, is based on a previous existing set of knowledge, and has the objective of creating new products or processes, or improving existing ones (OECD, 2015).
} 


\section{Review of the Relevant Literature}

The economic debates on fiscal decentralization and on R\&D knowledge spillovers constitute the theoretical basis of the model and of the empirical analysis presented in the next sections. This part reviews the main arguments and evidence presented by the literature on these topics.

\subsection{Fiscal decentralization, interregional spillovers and composition of public expenditures}

The "traditional branch" of the fiscal federalism theory (Oates, 2008a) gives clear guidelines for the division of functions between different levels of government. Following the decentralization theorem (Oates, 1972, 1999), local public goods should be more efficiently provided if decentralized to local governments, while global public goods and broad policies such as macroeconomic stability must be carried out at the national level. The original theorem, however, is based on the strong assumption that consumption of these goods is geographically defined. That means it only accepts the existence of "pure local" (consumption limited to a particular region or area) or global (that benefits all regions) goods (Kappeler \& Välilä, 2008).

This requirement was later relaxed by studies that admitted a third type of public goods that, in spite of being consumed locally, generates interregional spillovers that influence the production or welfare of people residing elsewhere (Besley \& Coate, 2003; Feidler \& Staal, 2012; Hulten \& Schwab, 1997; Oates, 2008a, 2008b; Ponce-Rodriguez, Hankla, Martinez-Vazquez, \& Heredia-Ortiz, 2012). These externalities reduce the incentives of local governments to invest in these goods, as part of the benefits arising from them is not internalized within the producing region. As a result, this leads to inefficient underprovision in a decentralized policy setup.

Four main approaches were suggested to deal with interregional spillovers. The original analysis by Oates $(1972,2008 b)$ merely acknowledges that there is a tradeoff between welfare gains of decentralization and inefficiency costs introduced by externalities, and calls for weighting these effects to decide whether a public good with these features is more efficiently provided by central or local governments. The second approach is the adoption of Pigouvian intergovernmental grants, designed to compensate subnational governments for their investments and therefore internalizing externalities (Oates, 1999, 2008a). The third one is a Coase type solution, in which subnational governments bargaining over externalities should reach an efficient solution for provision of a public good, assuming low transaction costs (Hulten \& Schwab, 1997). Finally, a political system of centralized parties can correct the inefficient underprovision of public goods, restoring the beneficial outcomes of decentralization (Ponce-Rodriguez et al., 2012).

The problem of interregional spillovers becomes more complicated as one introduces factor mobility. A strand of the literature argued that households or capital can move to more privileged locations to take advantage of lower taxes or higher levels of public goods or infrastructure. The 'Leviathan hypothesis' (Brennan \& Buchanan, 1980) suggests that fiscal decentralization limits the tax power and government size because local governments have to compete for constituents and resources. The corrosion of the tax base can also lead to an overall reduction of public services provision, also known as a 'race to the bottom' (Zodrow \& Mieszkowski, 1986), along with erosion of the welfare state and public infrastructure (Sinn, 2003), and reduction of gains arising from economies of scale (Hulten \& Schwab, 1997).

A different branch of the fiscal federalism literature analyzed how decentralization impacts the functioning of the government, both in terms of its political institutions and delivery of public policies (Martinez-Vazquez, Lago-Peñas, \& Sacchi, 2017). Part of these studies focused on the composition of government budget, although this is a relatively new and underexplored topic (Jia, Guo, \& Zhang, 2014). In theoretical terms, state competition should lead to a 'race to the top', the opposite outcome than the one described previously: in the model proposed by Keen and Marchand (1997), regions compete to attract investment, and as a result they overinvest in public input to business (such as infrastructure), at the cost of direct consumption benefits. Spending on education provides a similar example: once we allow for mobility of households, provinces compete to attract constituencies by raising their expenditure in this public good (Busemeyer, 2007).

Most of the literature on fiscal decentralization and composition of the public budget is comprised of empirically focused studies (for literature reviews, see Martinez-Vazquez, Lago-Peñas, and Sacchi 2017, 
and Granado, Martinez-Vazquez, and McNab 2005). Majority of them converge to the conclusion that higher decentralization levels lead to more public productive investment. There is evidence of this result for physical capital, infrastructure and housing (Jia et al., 2014; Kappeler \& Välilä, 2008; Sacchi \& Salotti, 2016), and for education or human capital (Ashworth, Galli, \& Padovano, 2009; Busemeyer, 2007; Faguet, 2004; Granado, Martinez-Vazquez, \& McNab, 2005; Kappeler \& Välilä, 2008; Sacchi \& Salotti, 2016), although at least in one case a negative impact on education was found (Jia et al., 2014). There is also evidence of positive impact on health (Granado et al., 2005; Kappeler \& Välilä, 2008) and pork-barrel expenses (Diaz-Cayeros, McElwain, Romero, \& Siewierski, 2002).

Some of the main expenditure categories that experience a reduction in their share of the government budget because of decentralization are welfare (Grisorio \& Prota, 2015) and social security (Ashworth et al., 2009; Fiva, 2005), following the results of the Keen and Marchand (1997) model.

Considering the importance of interregional spillovers, one expects that they should play an important role in determining how decentralization affects the composition of the public budget. However, most analyses did not expressly consider the case of local goods with interjurisdictional spillovers. As one of the exceptions, Kappeler and Välilä (2008) concluded that the impact of decentralization on these goods is ambiguous, depending on whether spillovers are dominantly local or global.

Finally, up to this point this literature has largely neglected the analysis of public expenditure in ST\&I. Only one of the studies in our literature review considered this spending category in the analysis (Grisorio \& Prota, 2015), but, even in this case, the authors did not use it in their econometric assessment.

\subsection{R\&D and knowledge spillovers}

The study of innovation policies has received great attention from economists of different schools of thought in the last decades (for recent reviews, see Edler et al. 2013, Edler and Fagerberg 2017, and Fagerberg 2017). In theoretical terms, there are sound grounds for public intervention in the field of ST\&I, mostly because market failures lead to an inefficient underinvestment in R\&D by private agents, thus requiring additional public resources to supplement it (Arrow, 1962; Hall, Mairesse, \& Mohnen, 2010; Köhler, Laredo, \& Rammer, 2012).

Among the failures identified by the literature, the incomplete appropriation of R\&D results is considered the most important economic rationale for innovation policies (Köhler et al., 2012). Positive externalities or knowledge spillovers are an intrinsic feature of innovation, because of the non-rival and non-excludable nature of knowledge, and also because of neglectable transmission costs (Arrow, 1962; Romer, 1990). The non-appropriated knowledge can be used by different firms and individuals for production and future research. As suggested in Romer's (1990) model, the marginal product of R\&D is higher than the return obtained by the R\&D-investing firm, because it only captures part of the value of the innovation, not benefiting from externalities. As the firm does not profit from or appropriate such spillovers, it also does not consider them in its spending decisions, leading to suboptimal investment levels. This justifies efficiency-enhancing government action to increase overall $R \& D$ spending through public subsidies or other incentives to promote private innovation investment.

As knowledge spillovers obtained a prominent role in innovation and economic growth analysis, a substantial empirical literature attempted to quantify them (for a review, see Hall, Mairesse, and Mohnen 2010). Most studies did find significant results (Wieser, 2005), and estimates suggest that they represent the highest share of innovation outcomes, reaching up to twice the value of internalized results or more (Bernstein \& Nadiri, 1989; Bloom, Schankerman, \& Van Reenen, 2013; Mansfield, Rapoport, Romeo, Wagner, \& Beardsley, 1977).

The impact of spillovers, however, is not even across firms, and geographical distance plays a major role in their dispersal. These externalities are considered spatially localized, as firms located in the same region or country where the technology is developed tend to benefit more from it. Peri (2005) estimated that no more than $20 \%$ of created knowledge goes outside the region of origin, and less than $9 \%$ leaves the country. There is also evidence that firms located close to academic centers are more likely to apply their research findings first (Mansfield \& Lee, 1996), and that basic research cooperation decreases with distance (Katz, 1994). The main explanations presented for this geographic concentration are the tacit nature of knowledge, geographic barriers to knowledge flows, linguistic factors and agglomeration of production 
(Audretsch \& Feldman, 1996; Maurseth \& Verspagen, 2002). But the strength of these factors may be temporary, as there is evidence suggesting that knowledge spillovers are only local in the short run, and that such concentration fades over time (Jaffe, Trajtenberg, \& Henderson, 1993).

Spillovers also positively affect productivity at the international level (Coe, Helpman, \& Hoffmaister, 2009; Malerba, Mancusi, \& Montobbio, 2013; Mancusi, 2008). Coe and Helpman (1995) concluded that about a quarter of total benefits of R\&D in G7 countries spillovers to their trading partners. The magnitude of this result depends on the channels of transmission considered in the analysis, although the existence of substantial international knowledge externalities is generally unchallenged (Hall et al., 2010).

The geographic dispersal of knowledge spillovers can be influenced by different factors. A first one is the nature of innovative R\&D. In his seminal article, Nelson (1959) argued that while basic research is the major source of scientific breakthroughs and significant technology developments, it presents 'substantial external economies', as its results can be used in different fields. Consequently, private firms should invest even less in this activity, calling for a greater role of public and non-profit organizations in funding infrastructure and projects (JEC, 2010).

The same argument has been suggested in different studies (Akcigit, Hanley, \& Serrano-Velarde, 2013; Chu \& Furukawa, 2013; Shapiro \& Taylor, 2013), and Schumpeterian growth models also considered that basic research yields more knowledge spillovers, and, for this reason, it is particularly important for economic growth (Aghion \& Howitt, 1996). Empirical analyses confirmed that large spillovers arise from basic research (Salter \& Martin, 2001): Funk (2002) found that it generates much larger international spillovers; Griliches (1985), Mansfield (1980) and Lichtenberg and Siegel (1991) identified a "premium" for basic research, meaning that it is more important for productivity increase than other types of R\&D; and Mansfield (1991) estimated a 28\% social rate of return of academic research in the late 1970s.

A second factor to be considered when analyzing the spreading of knowledge spillovers is whether it arises from private or public research. Research on this distinction is still scarce, and the evidence related to public R\&D is mostly focused on specific government research projects (Salter \& Martin, 2001), but it suggests that the difference can be substantial. In an analysis of pharmaceutical research, Furman et al. (2006) noticed that locally generated knowledge is positively correlated with research productivity, provided that it comes from public R\&D, and that the correlation becomes negative in the case of private research.

The literature review presented in this section suggests that there might be important links between the level of fiscal decentralization of a country and its public investment in innovation, a topic that so far has not been explored by the economic literature. The model presented in the next section is a first attempt to fill this gap. Following the studies discussed herein, the main factors that explains the relation between these variables are the presence of knowledge spillovers with uneven geographic spreading, state competition and the type of R\&D (basic or applied) financed by the government.

\section{Theoretical model: linking fiscal decentralization and public $R \& D$}

As the product of R\&D activities, innovation presents typical features of public goods, i.e., nonrivalry and non-excludability (Arrow, 1962), and for this reason it is treated as such in different studies (Malerba et al., 2013; Verspagen, 1992; Verspagen \& De Loo, 1999). A substantial share of its results constitutes positive externalities that are not internalized by firms incurring the respective costs, and that partially flow to other states and countries. These features suggest that government investment in $R \& D$ activities can be considered a case of local public good with interjurisdictional spillovers, and therefore they should be affected by the level of fiscal decentralization of a country.

Considering the concepts and arguments discussed in the previous section, we present a simple model to explain how fiscal decentralization affects the share and composition of government expenditures in $\mathrm{R} \& \mathrm{D}$, considering the broad categories of basic and applied research (as defined below). The model details the economic forces that shape the decision of a 'benevolent government' that aims to maximize net income in the country or in the respective region in the short run (Besley \& Coate, 2003; Dhillon, Wooders, \& Zissimos, 2007; Zodrow \& Mieszkowski, 1986). Following similar analysis (Besley \& Coate, 2003; 
Dhillon et al., 2007; Feidler \& Staal, 2012), the effects of decentralization are assessed by comparing the optimal decision of central and regional governments, both from the perspective of revenue (the power to collect taxes and determine applicable rates) and expenditure (composition of spending).

The formal specification of the model is based on two streams of literature: (a) fiscal decentralization models with interjurisdictional spillovers (Besley \& Coate, 2003; Feidler \& Staal, 2012; Granado et al., 2005; Oates \& Schwab, 1988) and with public goods as inputs to production (Dhillon et al., 2007; Zodrow \& Mieszkowski, 1986) are used to design government incentives and decisions at the national and lower levels; and (b) Schumpeterian endogenous growth models (Aghion \& Howitt, 1992, 1998) and their extensions to include basic research (Aghion \& Howitt, 1996; Cozzi \& Galli, 2009) and public R\&D (Morales, 2004) provide the description of the innovation process and its contribution to output.

\subsection{Basic Setup}

We consider a model with discrete time periods $(t=1,2, \ldots m)$ and a closed economy divided in a large number of $(n)$ similar and symmetric regions, with only one homogeneous final good sold at the same competitive price (set at one for simplicity) and produced by $(n)$ firms, one located in each region. We abstract from changes in population by assuming a constant number of uniformly distributed and nonmoving individuals (Oates \& Schwab, 1988). Capital, on the other hand, is perfectly mobile across jurisdictions, and it is allocated by its owners at each period to maximize earnings. The total stock of capital in this society $(\bar{K})$ is fixed in the short run (Oates \& Schwab, 1988; Zodrow \& Mieszkowski, 1986), and its ownership is evenly distributed among all individuals, so that constituents of each region own $(\bar{k} / \mathrm{n})$ units of capital. Gross regional output in region $(i)$ at period $(t)$ depends on the capital $\left(k_{i t}\right)$ invested in the firm located therein and on the production technology level of each firm $\left(A_{i t}\right)$, following a standard CobbDouglas production function.

Firms compete to attract capital by paying an interest rate $\left(r_{t}\right)$, but as capital is perfectly mobile and there is a large number of communities, competition equals such rate among all jurisdictions (Zodrow \& Mieszkowski, 1986). In addition, firms have to pay taxes that levy on each unit of capital invested at the respective period, according to a tax rate $\left(z_{i t}\right)$ set by the government. In this scenario, the net income of a region is given by the gross output minus taxes and interest paid by the firm, plus interest received by capital owners in the region, as presented in Equation 1:

$y_{i t}=k_{i t}^{\alpha} A_{i t}^{1-\alpha}-k_{i t}\left(z_{i t}+r_{t}\right)+(\bar{K} / n) r_{t} \quad ; \quad 0<\alpha<1$

The public budget $\left(G_{i t}\right)$ is balanced, so there is no public savings or deficit, and it is entirely spent in public R\&D investment. We assume that the central government spends all taxes in the same region where they are collected, so we can abstract from regional transfers. The public spending constraint for each region in each period is therefore:

$G_{i t}=k_{i t} z_{i t}$

Firms in all regions begin at the same technology level $\left(A_{i, t-1}\right)$, so we do not have to consider regional disparities. Their state of technology evolves according to the investment made by the government in $R \& D$ within the region $\left(G_{i t}\right)$, and to knowledge spillovers captured from public R\&D performed in all other regions $(h()$.$) , as presented in Equation 3. R\&D is broadly divided in basic and applied research (Morales,$ 2004; Park, 1998) according to the variable $\left(0<b_{i t}<1\right)$, that informs the share of public R\&D devoted to basic research as set by the government. Similarly, spillovers from other regions can be divided in basic and applied knowledge. In order to preserve the tractability and simplicity of the model, spillovers only affect the technology state directly, with no second order impacts on the results of locally-performed R\&D.

$$
\Delta A_{i t}=A_{i t}-A_{i, t-1}=G_{i t} f\left(b_{i t}\right)+h\left(G_{j t}, b_{j t}\right) \quad ; \quad j \neq i
$$


The main distinction between basic and applied research considered herein is that basic research generates the knowledge necessary for innovations, but it does not improve the technology by itself, meaning that applied research is required to apply such knowledge to the production process (Auerswald, Branscomb, Demos, \& Min, 2003; Morales, 2004). Investment in applied research, on the other hand, is a sufficient condition to improve technology, for it can be based on incremental or secondary innovation (Aghion \& Howitt, 1998), but its productivity and results are improved by basic research knowledge. This description suggests the following functional form for the R\&D productivity factor: ${ }^{2}$

$f\left(b_{i t}\right)=\left(1-b_{i t}\right)\left(\theta\left(1-s_{A}\right)+b_{i t} \gamma\left(1-s_{B}\right)\right)$

\section{Where}

$s_{b}>s_{a}$

Positive parameter $(\theta)$ represents the productivity of applied research, $(\gamma)$ is the contribution of basic research to productivity improvement, and $\left(s_{b}\right)$ and $\left(s_{a}\right)$ are the levels of interregional spillovers of basic and applied research, respectively. As suggested by the literature discussed in section 2, we assume that interjurisdictional spillovers represent a higher share of results in the case of basic research (Equation 4.1). These spillovers are distributed among all regions (other than the one producing them) equally, so that each receives an equal share of externalities arising from R\&D performed in all other $(n-1)$ jurisdictions, as presented in Equation 5.

$h\left(G_{j t}, b_{j t}\right)=\sum_{j=1}^{n-1}\left(\left(\frac{1}{n-1}\right) G_{j t}\left(1-b_{j t}\right)\left(\theta\left(s_{A}\right)+\gamma b_{i t}\left(s_{B}\right)\right)\right)=G_{j t}\left(1-b_{j t}\right)\left(\theta\left(s_{A}\right)+\gamma b_{i t}\left(s_{B}\right)\right) ; j \neq i$

\subsection{The Regional Government Decision}

We first consider the case of complete decentralization, where regional governments are the only tax authorities and have full discretion to decide on their spending. The government aims to maximize net local income, as provided in Equation 1. To achieve this goal, it taxes locally-invested capital and spends the public budget on public R\&D, determining the composition of its investment bundle.

While establishing the applicable tax rate, regional governments have to consider the impact of their decisions on capital investment. Capital is perfectly mobile, so firms have no control over the applicable interest rate. As Equation 1 provides for diminishing returns of factors, firms will take additional capital up to the point where its marginal product net of taxes equals the applicable tax rate. For this reason, as in Oates and Schwab (1988), the capital constraint of the regional government's maximization problem is :

$\alpha\left(\frac{A_{i t}}{k_{i t}}\right)^{1-\alpha}-z_{i t}=r_{t}$

The regional government trade-off concerning the tax rate can be described as follows: while taxes provide funding for public R\&D that improves the production technology $\left(A_{i t}\right)$ and increase output (Equation 3), they negatively impact the net income through two effects: (a) directly, by reducing the capital available for production (Equation 1); and (b) indirectly, by reducing the marginal product of capital. The level of taxation is then chosen to maximize local net income according to Equation 1, subject to the budget and capital constraints in Equations 2 and 6, and the expected technology improvement in the province (Equation 3). Taking the first order conditions and solving the system of equations, we find the optimal tax rate of the regional government $\left(z_{i}^{R *}\right)$.

\footnotetext{
2 This functional form is a combination of the specification of basic and applied research suggested by Morales (2004) and the effect of spillovers defined by Feidler and Staal (2012).
} 
$\frac{\partial y_{i t}^{c}}{\partial z_{i t}}=0 \rightarrow z_{i}^{R *}=\left((1-\alpha) f_{i}^{R *} r_{t}\right)^{1-\alpha} \alpha^{\alpha}-r_{t}$

$f_{i}^{R *}=\left(1-b_{i}^{R *}\right)\left(\theta\left(1-s_{A}\right)+\gamma b_{i}^{R *}\left(1-s_{B}\right)\right)$

Equation 7 informs how the optimal tax rate is affected by competition in the capital market. Such impact is two-folded, as suggested by the presence of the interest rate parameter $\left(r_{t}\right)$ in both terms of Equation 7: on the one hand, state competition limits the tax rate, as an increase would cause a capital flight and therefore reduce output; but, on the other hand, the additional public R\&D raises the gross marginal product of capital, attracting investment (for the same reason, taxation increases with the R\&D productivity factor).

To decide on the composition of the public R\&D bundle, the government considers the expected technology improvement caused by additional units of basic and applied research, and the respective impact on output. Spillovers affect such decision because part of the new developed technology cannot be appropriated and therefore does not generate additional income in the region. The optimal composition of the public R\&D bundle ( $\left.b_{i t}^{R *}\right)$ is obtained by maximizing the technology level in Equation 3 with respect to the share of basic research $\left(b_{i t}\right)$. The efficient share of basic research $\left(b_{i}^{R *}\right)$ displayed in Equation 8 is positively correlated with its own contribution $(\gamma)$, and negatively correlated with the applied research productivity $(\theta)$. As expected, the influence of these parameters in the optimal composition rate is reduced by the respective interjurisdictional spillovers, as these results are not accounted for by regional governments in their decision.

$\frac{\partial A_{i t}}{\partial b_{i t}}=0 \Rightarrow b_{i}^{R *}=\frac{1}{2}-\frac{\theta\left(1-s_{A}\right)}{2 \gamma\left(1-s_{B}\right)}$

\subsection{The Central Government Decision}

We now consider the optimal decision of the central government in a scenario of total centralization of both the tax policy and public expenditure. In this case, the government aims to maximize net national income $\left(y_{t}{ }^{C}\right)$. To achieve this goal, it sets a single applicable tax rate and composition of the public R\&D bundle for all regions $\left(z_{i t}=z_{j t}=z_{t}\right.$ and $\left.b_{i t}=b_{j t}=b_{t}\right)$. As all capital is owned by individuals within the country, capital compensation payments are offset by the respective interest revenue obtained in all regions.

$y_{t}^{C}=\sum_{i=1}^{n}\left(k_{i t}^{\alpha} A_{i t}^{1-\alpha}-k_{i t}\left(z_{i t}+r_{t}\right)+(\bar{K} / n) r_{t}\right)=n\left(k_{i t}^{\alpha} A_{i t}^{1-\alpha}-k_{i t} z_{i t}\right)$

The first main difference between the centralized and decentralized government cases is the capital constraint. For the central government, the level of capital is constrained only by the total stock available in the economy $(\bar{K})$, assumed to be fixed in the short run. As both the interest and tax rates are the same for all firms, the assumption of similar regions ensure that capital is equally invested in all regions:

$\bar{k}=\sum_{i=0}^{n} k_{i t} \rightarrow k_{i t}=\frac{\bar{k}}{n}$

The second difference is the technology function. The central government considers interjurisdictional knowledge spillovers along with internal results, as the value that does not accrue to the firm in one region improves the production technology in all others, so there is no externality loss (or gain) at the national level. This effect is represented by the sum of all regional outputs in Equation 9. A different way to understand this is to apply the national rates to the spillover and R\&D productivity functions (Equations 4 and 5) and substitute it in the R\&D Equation (3). The similar regions assumption ensures that, for each firm, the value of externalities flowing out of the jurisdiction is equivalent to spillovers captured from $R \& D$ in all other areas, leading to the technology improvement function presented in Equation 11, that does not consider the spillovers parameters: 
$A_{t}=A_{t-1}+(\bar{k} / n) z_{t}\left(1-b_{i t}\right)\left(\theta+b_{i t} \gamma\right)$

The optimal level of taxation $\left(z_{t}^{C *}\right)$ is obtained by maximizing the national output in Equation 9, subject to the capital constraint and the expected technology improvement (Equations 10 and 11, respectively). The optimal rate (displayed in Equation 12) increases with capital availability and the R\&D productivity factor (as it raises the marginal product of public innovation), and it decreases with the initial level of technology (because of diminishing returns in the production function).

$\frac{\partial y_{t}^{c}}{\partial z_{t}}=0 \rightarrow z^{C *}=(1-\alpha)^{\frac{1}{\alpha}}\left(f^{C *}\right)^{\frac{1-\alpha}{\alpha}}-\frac{A_{i, t-1}}{\left(f^{C *}\right)(\bar{k} / n)}$

$f^{C *}=\left(1-b^{C *}\right)\left(\theta+\gamma b^{C *}\right)$

The central government's optimal choice for the composition of the public R\&D bundle is the one that maximizes technological development in Equation 11, and, consequently, net national output. Equation 13 follows closely the specification of the best choice of the decentralized government (Equation 8), without taking into consideration parameters of externalities that flow to other provinces.

$\frac{\partial A_{t}}{\partial b_{t}}=0 \rightarrow b^{C *}=\frac{1}{2}-\frac{\theta}{2 \gamma}$

The economic interpretation of these results is as follows: for small values of $\left(b_{t}\right)$, an increase in basic research spending creates new knowledge that substantially improves the results of applied research. As a result, the central government raises taxes, improves the technology and final net output is increased. Such movement continues until the share of basic research reaches $b^{C *}$, where the marginal contribution of public R\&D equals the cost of an additional unit of tax to output. After such point, the level of applied research to transform additional knowledge in commercial application is insufficient, and further basic research becomes sterile with a negative impact on technological development (as in Aghion and Howitt's 1998 model with secondary innovation). As the contribution of further public R\&D to net output falls short of its marginal cost, the government reduces taxes, but aggregate net production is still reduced.

\subsection{Effects of decentralization}

The main difference between the two cases is that regional governments do not consider knowledge spillovers that do not accrue to the local economy. This is best represented by the optimal composition of the public R\&D bundle. While the decision of the central government (Equation 13) is solely based on the basic and applied research productivity parameters, the optimal decentralized decision (Equation 8) weights them according to the level of spillovers applicable to each type of R\&D. As a result, the regional government optimally chooses a lower share of basic research, considering that it yields more interjurisdictional externalities (as assumed). This is the first main conclusion of the model to be empirically tested in the next section.

Proposition 1: $b^{C *}>b^{R *}$. All other things constant, a higher level of fiscal decentralization should lead to a lower intensity of basic research within the public $R \& D$ bundle, as a lower share of its results stays within the region. Conversely, the effect of fiscal decentralization on the share of applied research in the public innovation bundle is positive.

The optimal level of taxation is also affected by regional spillovers. As the contribution of public $\mathrm{R} \& \mathrm{D}$ to regional product is smaller than to national output, regional governments tend to spend less on $\mathrm{R} \& \mathrm{D}$. This is represented by the value of the R\&D productivity factor in Equations $7 \mathrm{a}$ and $12 \mathrm{a}$. As in the decentralized case the factor is reduced by the spillover parameters, it is easy to see that $f^{C *}>f^{R *}$. However, when taxes are defined at the regional level, they also influence the level of capital investment in 
each region, and this is considered by the government. Such effect, however, is ambiguous, because of reduced net capital gain and increased gross marginal product of capital.

Therefore, the overall impact of decentralization on the taxation level or size of the public R\&D investment depends on the value of the parameters. This result is in accordance with the conclusions of Kappeler and Välilä (2008), who argued that the final outcome of decentralization cannot be determined theoretically a priori in the presence of state competition and interregional spillovers. Nevertheless, we argue that, in light of the optimal tax rates expressed in Equations 7 and 12, innovation spending tends to be lower in a decentralized environment. Although state competition can make regional authorities increase R\&D spending to attract investment, two opposing forces counterbalance this positive effect: first, reduced capital gains caused by higher taxes; and second, interregional spillovers. Combined, these two forces tend to be dominant, causing the tax rate established by the regional government to be lower than the one determined by a centralized tax authority. This constitutes the second proposition to be tested in the empirical analysis described in the next section.

Proposition 2: $z^{C *}>z^{R *}$. 'Ceteris paribus', a higher level of fiscal decentralization should lead to a lower level of public spending on innovation, as a consequence of knowledge spillovers and of state competition to attract capital.

\section{Empirical Analysis}

In this part, we present a quantitative analysis to test the two propositions derived from the model, as stated above. For such purpose, we investigate whether the level of fiscal decentralization has statistically significant effects on government spending on $R \& D$, considering a group of four variables: (a) the share of basic research in the total public budget; (b) the share of 'applied research and development' 3 expenditures; (c) the overall share of R\&D spending; and (d) the share of basic research within the public R\&D bundle.

\subsection{Specification of the empirical model}

We assume that the public R\&D budget is determined by governments in light of economic, technological and demographic features of the country, the political orientation of the party controlling the national executive branch, and broader decisions related to the public budget.

As public innovation yields different payoffs for central and regional governments, such decision is also affected by the country's level of fiscal decentralization, measured as the share of subnational levels of government in general government revenue (excluded intergovernmental grants) or spending. We consider these two cases of decentralization in separate estimates, as they tend to be highly correlated, reducing the efficiency of the regressions. However, as the difference between government's revenue and spending may be a relevant variable to explain public budget (Eyraud \& Lusinyan, 2013), we introduce a variable that represents imbalance in decentralization, calculated as the difference between the revenue and expenditure decentralization levels.

We consider that all variables that affect government budget contemporaneously, following the specification in different empirical papers (Alegre, 2010; Ashworth et al., 2009; Busemeyer, 2007; Fiva, 2005; Granado et al., 2005). In addition, as governments may face non-neglectable adjustment costs on budget composition, we introduce lagged versions of the dependent variables as explanatory ones to account for path dependency.

Considering this description, we use the following reduced-form specification to assess the effects of decentralization on public R\&D:

$$
d e p_{-} \text {var }_{i t}=\beta_{0}+\beta_{1} \text { dep_var }_{i, t-1}+\beta_{2} \operatorname{dec}_{i t}+c_{i t}+f_{i}+\beta y e a r_{t}+u_{i t}
$$

\section{Where}

\footnotetext{
${ }^{3}$ Applied research and development are considered jointly, as they are not distinguished in the IMF Government Finance Statistics database (IMF, n.d.).
} 
dep_var $_{i t}=$ basic $_{i t} ; \operatorname{applied}_{i t} ; r d_{i t}^{\text {tot }} ; b_{i t}$

$d e c_{i t}=d e c_{-} \exp _{i t} ; d e c_{-} r e v_{i t}$

$c_{i t}=\beta_{3}$ govsize $_{i t}+\beta_{4}$ budget $_{i t}+\beta_{5}$ imbalance $_{i t}+\beta_{6}$ gdp $p_{i t}+\beta_{7}$ trade $_{i t}+\beta_{8}$ industry $_{i t}+$ $\beta_{9}$ unemploy $_{i t}+\beta_{10}$ pop $_{i t}+\beta_{11}$ educ $_{i t}+\beta_{12}$ patent $_{i t}+\beta_{13}$ ht_exp $p_{i t}+\beta_{14}$ orient_right $_{i t}+$ $\beta_{15}$ orient_left $_{i t}$

Where $\left(\right.$ dep_var $\left._{i t}\right)$ represents one of the four dependent variables, $\left(\right.$ basic $\left._{i t}\right),\left(\right.$ applied $\left._{i t}\right)$ and $\left(r d_{i t}^{\text {tot }}\right)$ are the shares of the public budget allocated to basic research, 'applied research and development' ${ }^{4}$, and total $\mathrm{R} \& \mathrm{D}$, respectively, and $\left(b_{i t}\right)$ is the intensity of basic research in public R\&D spending. $\left(d e c_{i t}\right)$ is the main explanatory variable of interest, representing the level of decentralization of public revenue ( dec_revit $_{\text {) }}$ or expenditure (dec_expit) of each country. $\left(c_{i t}\right)$ is a vector of control variables that influence or are taken into consideration by the government to determine its R\&D budget. Broader decisions on government accounts considered herein are the size of government (public expenditure as share of country's gross domestic product (GDP) - govsize $i t$ ), budget balance (budget ${ }_{i t}$ ), and level of decentralization imbalance (imbalance $\left.{ }_{i t}\right)$. The variables that represent economic activity are GDP per capita $\left(g d p_{i t}\right)$, trade openness (trade tr $_{\text {) }}$ - import plus exports as share of GDP, industrialization level or industry value-added as share of GDP (industry $y_{i t}$ ), and unemployment levels (unemploy $\left.{ }_{i t}\right)$. Population size $\left(\right.$ pop $_{i t}$ ) and share of population with tertiary education (educit) are considered to account for demographic and human capital differences. We control for distinct levels of technological development by including variables representing patent application per resident (patent $\left.{ }_{i t}\right)$ and high-technology exports as share of manufactured exports $\left(h t \_\exp _{i t}\right)$. And, finally, dummies for orientation of chief executive party with respect to economic policy (orient_right ${ }_{i t}$ and orient_left $t_{i t}$ for right and left wing orientations) ${ }^{5}$ are also included. Source and descriptive statistics of all variables are presented in Table 1, section 4.3.

The model also considers country time-invariant features or fixed effects $\left(f_{i}\right)$, time dummies $\left(\right.$ year $\left._{t}\right)$ to account for international trends that affected all nations equally, and an error term $\left(u_{i t}\right)$.

\subsection{Identification Strategy}

Almost all empirical studies in our literature review acknowledged that unobservable country features affect the composition of government spending, which may lead to inconsistent estimates. Following this literature, we expect endogeneity arising from differences in countries' development levels and other factors, and therefore we estimate the parameters of interest of Equation 14 using two-step system-GMM (Arellano \& Bond, 1991; Arellano \& Bover, 1995; Blundell \& Bond, 1998), considered the 'workhorse in estimating dynamic panel data' (Kappeler \& Välilä, 2008) and used in different studies (Alegre, 2010; Jia et al., 2014; Sacchi \& Salotti, 2016).

The estimating technique may be intuitively described as follows: the first step is to exclude timeinvariant fixed effects $\left(f_{i}\right)$ by first-differencing all variables. However, as this does not solve the problem of endogenous regressors, lagged versions of all variables can be used as instruments, assuming no serial correlation between errors (the original GMM developed by Arellano and Bond 1991). But this assumption is often not valid for dynamic panels (Blundell \& Bond, 1998), and for this reason Arellano and Bover (1995) improved the estimator through a system of equations in which lagged differences are used as instruments for equations in levels and vice-versa. Consistency of the estimates is mostly conditioned upon instruments being exogenous, which is commonly assessed through over-identification and second-order correlation in differences tests (Roodman, 2006).

\footnotetext{
4 Government functions present in the dataset are: public services; defense; public order and safety; economic affairs; environmental affairs; housing and facilities; health; culture; education; and social protection (IMF, n.d.).

5 Following the definitions presented in Cruz, Keefer, and Scartascini (2016, p. 8): "Right: for parties that are defined as conservative, Christian democratic, or right-wing. Left: for parties that are defined as communist, socialist, social democratic, or left-wing." Dummy variable for center orientation of the chief executive party was excluded to avoid perfect collinearity with other political dummies.
} 
In practical terms, we apply the system-GMM to estimate the coefficients of Equation 14, assuming that none of the explanatory variables are exogenous (except for time dummies). Statistical significance is assessed at a 95\% confidence level. Considering the gaps in our unbalanced panel, we apply forward orthogonal deviations transformation (Arellano \& Bover, 1995); and in light of the limited number of observations, we reduce instrument count by collapsing them into a column vector instrument (Roodman, 2006) and applying principal components analysis (Mehrhoff, 2009). Exogeneity of the instruments is assessed through the Sargan over-identification and Arellano-Bond second-order correlation (AR(2)) tests, and the Kaiser-Meyer-Olkin (KMO) test for sampling adequacy is applied to check whether the instruments chosen are representative of the entire sample.

\subsection{Data}

The data used for this empirical analysis were collected from different sources and organized in a panel dataset that contains observations for 47 countries in different years, covering the period of 1995 to $2015^{6}$. However, comparable data on public innovation spending is still not available for many countries, or in many cases there is information only for a limited number of years. For this reason, our dataset constitutes an unbalanced panel with missing values for different countries and periods.

Table 1 informs the source and descriptive statistics of all variables used in this empirical study. Data related to government revenue and spending, including the public R\&D dependent variables, come from the IMF Government Finance Statistics database (IMF, n.d.). Basic research, applied research and development in this dataset (IMF, 2014) have the same definition presented in OECD (2015). Basic research is classified as part of public services expenditure, and the variable for total 'applied research and development' represents the sum of these expenditures for all functions of government. Total R\&D spending constitutes the sum of values for basic research and 'applied research and development'.

Table 1

Descriptive statistics of variables used in the empirical study

\begin{tabular}{|c|c|c|c|c|c|c|}
\hline Variable & $\mathrm{n}$ & Mean & Std. Dev. & Min & Max & Data Source \\
\hline \multicolumn{7}{|c|}{ Dependent variables - Government R\&D categories as share of total government expenditures } \\
\hline basic $_{i t}$ & 446 & 0.872 & 0.699 & 0.000 & 3.181 & \multirow{4}{*}{$\begin{array}{c}\text { IMF Government } \\
\text { Finance Statistics (IMF, n.d.) }\end{array}$} \\
\hline applied $_{i t}$ & 406 & 1.204 & 0.775 & 0.000 & 3.638 & \\
\hline$r d_{i t}{ }^{\text {tot }}$ & 406 & 2.099 & 1.071 & 0.000 & 5.311 & \\
\hline$b_{i t}$ & 406 & 40.292 & 27.481 & 0.000 & 100.000 & \\
\hline \multicolumn{7}{|c|}{ Explanatory Variables } \\
\hline dec_exp it & 446 & 30.365 & 16.226 & 0.000 & 65.630 & \multirow{5}{*}{$\begin{array}{c}\text { IMF Government } \\
\text { Finance Statistics }(I M F, \text { n.d.) }\end{array}$} \\
\hline dec_revit & 446 & 16.413 & 12.372 & 0.000 & 51.700 & \\
\hline imbalance $_{i t}$ & 446 & -13.952 & 8.805 & -38.970 & 5.270 & \\
\hline gov_size $_{i t}$ & 446 & 42.829 & 8.206 & 14.330 & 63.900 & \\
\hline budget $_{i t}$ & 446 & -0.950 & 4.929 & -30.700 & 19.960 & \\
\hline$g d p_{i t}$ & 446 & 31233.360 & 20509.830 & 1530.060 & 117507.800 & \multirow{8}{*}{$\begin{array}{l}\text { World Bank Development } \\
\text { Indicators }(W B, 2017)\end{array}$} \\
\hline population $_{i t}$ & 446 & 20779.800 & 27655.050 & 327.320 & 143456.900 & \\
\hline trade $_{i t}$ & 446 & 102.417 & 53.052 & 24.490 & 438.160 & \\
\hline unemploy $_{i t}$ & 446 & 8.202 & 4.554 & 0.510 & 27.470 & \\
\hline industry $_{i t}$ & 446 & 27.808 & 5.871 & 10.720 & 44.800 & \\
\hline education $_{\text {it }}$ & 446 & 10.955 & 1.465 & 2.300 & 13.400 & \\
\hline patent $_{i t}$ & 446 & 292.274 & 383.901 & 0.098 & 2271.464 & \\
\hline ht $\exp _{i t}$ & 446 & 16.154 & 10.838 & 0.000 & 60.000 & \\
\hline orient_right $t_{i t}$ & 446 & 0.401 & 0.491 & 0.000 & 1.000 & IDB Database of Political \\
\hline orient left $_{i t}$ & 446 & 0.330 & 0.471 & 0.000 & 1.000 & Institutions 2015 (Cruz et al., 2016) \\
\hline
\end{tabular}

\subsection{Estimation results}

The estimated coefficients for the empirical model and their statistical significance are presented in Table 2 below, along with the results of the over-identification, serial correlation and sampling adequacy tests. In none of the cases the AR(2) test rejects the hypothesis of no second-order correlation of differenced residuals, suggesting that the instruments are orthogonal to the error terms. The Sargan test also does not

${ }^{6}$ List of countries and years available upon request to the authors. 
reject exogeneity of the instruments for any of the regressions. And the Kaiser-Meyer-Olkin test for sampling adequacy indicates that the principal component analysis reduced the number instruments without losing relevant identifying information. These results indicate that the lagged variables used as instruments efficiently mitigate endogeneity problems, reducing bias and increasing consistency of the results.

Table 2

Estimation results: expenditure and revenue decentralization

\begin{tabular}{|c|c|c|c|c|c|c|c|c|}
\hline \multirow{3}{*}{$\begin{array}{l}\text { Explanatory } \\
\text { Variables } \\
\end{array}$} & \multicolumn{8}{|c|}{ Dependent Variable } \\
\hline & \multicolumn{4}{|c|}{ Expenditure Decentralization } & \multicolumn{4}{|c|}{ Revenue Decentralization } \\
\hline & basic $_{i t}$ & applied $_{i t}$ & $r d_{i t}^{\text {tot }}$ & $b_{i t}$ & basic $_{i t}$ & applied $_{\text {it }}$ & $r d_{i t}^{\text {tot }}$ & $b_{i t}$ \\
\hline \multirow[t]{2}{*}{$(\text { dep.var. })_{i, t-1}$} & 0.000 & 0.000 & $0.737 * * *$ & $1.029 * * *$ & 0.000 & 0.000 & 0.000 & $0.968^{*}$ \\
\hline & $(0.000)$ & $(0.000)$ & $(0.060)$ & $(0.126)$ & $(0.000)$ & $(0.000)$ & $(0.000)$ & $(0.565)$ \\
\hline \multirow[t]{2}{*}{$d e c_{i t}$} & $-0.023 * * *$ & 0.016 & $-0.032 * *$ & $-0.626 * *$ & $-0.066 * * *$ & $-0.042 * * *$ & $-0.070 * * *$ & 0.631 \\
\hline & $(0.002)$ & $(0.014)$ & $(0.015)$ & $(0.317)$ & $(0.004)$ & $(0.007)$ & $(0.007)$ & $(1.177)$ \\
\hline \multirow[t]{2}{*}{ imbalance $_{\text {it }}$} & 0.000 & $0.062 * * *$ & $-0.032 *$ & $-1.071 * *$ & $0.071 * * *$ & $-0.063 * * *$ & $0.036 * * *$ & -0.597 \\
\hline & $(0.000)$ & $(0.016)$ & $(0.016)$ & $(0.508)$ & $(0.004)$ & $(0.004)$ & $(0.011)$ & $(0.680)$ \\
\hline \multirow[t]{2}{*}{ gov_size $_{i t}$} & 0.000 & -0.008 & $0.031 * * *$ & 0.424 & $0.022 * * *$ & $-0.040 * * *$ & $0.024 * * *$ & 0.011 \\
\hline & $(0.000)$ & $(0.020)$ & $(0.011)$ & $(0.425)$ & $(0.003)$ & $(0.009)$ & $(0.004)$ & $(0.802)$ \\
\hline \multirow[t]{2}{*}{$g d p_{i t}$} & $0.000 * * *$ & $0.000 * * *$ & $0.000 * * *$ & -0.000 & $0.000 * * *$ & $0.000 * * *$ & $0.000 * * *$ & -0.000 \\
\hline & $(0.000)$ & $(0.000)$ & $(0.000)$ & $(0.000)$ & $(0.000)$ & $(0.000)$ & $(0.000)$ & $(0.001)$ \\
\hline \multirow[t]{2}{*}{ population $_{i t}$} & $0.000 * * *$ & $0.000^{*}$ & -0.000 & 0.000 & $-0.000 * * *$ & 0.000 & $0.000 * * *$ & -0.000 \\
\hline & $(0.000)$ & $(0.000)$ & $(0.000)$ & $(0.000)$ & $(0.000)$ & $(0.000)$ & $(0.000)$ & $(0.000)$ \\
\hline \multirow[t]{2}{*}{ trade $_{i t}$} & $0.004 * * *$ & $0.026 * * *$ & $-0.005 * * *$ & 0.009 & $-0.007 * * *$ & $0.008 * * *$ & $0.008 * * *$ & -0.062 \\
\hline & $(0.000)$ & $(0.002)$ & $(0.002)$ & $(0.038)$ & $(0.000)$ & $(0.001)$ & $(0.001)$ & $(0.100)$ \\
\hline \multirow[t]{2}{*}{ unemploy $_{i t}$} & $-0.027 * * *$ & $-0.109 * * *$ & $-0.021 *$ & 0.055 & $0.013 * * *$ & 0.000 & $-0.087 * * *$ & -1.142 \\
\hline & $(0.004)$ & $(0.016)$ & $(0.012)$ & $(0.234)$ & $(0.003)$ & $(0.000)$ & $(0.008)$ & $(1.473)$ \\
\hline \multirow[t]{2}{*}{ orient_right $_{i t}$} & $-0.377 * * *$ & $0.147 * * *$ & $0.330 * * *$ & -1.992 & $0.425 * * *$ & $-0.272 * * *$ & $-0.138 * * *$ & 1.704 \\
\hline & $(0.028)$ & $(0.049)$ & $(0.071)$ & (2.108) & $(0.022)$ & $(0.027)$ & $(0.047)$ & $(2.906)$ \\
\hline \multirow{2}{*}{ orient_left $_{i t}$} & 0.000 & 0.000 & $0.436 * * *$ & $-4.848 * *$ & $0.845 * * *$ & 0.000 & 0.000 & 1.449 \\
\hline & $(0.000)$ & $(0.000)$ & $(0.098)$ & $(2.080)$ & $(0.029)$ & $(0.000)$ & $(0.000)$ & $(6.195)$ \\
\hline \multirow{2}{*}{ industry $_{i t}$} & $-0.010 * * *$ & -0.013 & 0.000 & -0.439 & $0.061 * * *$ & $0.046^{* * *}$ & $-0.064 * * *$ & -1.501 \\
\hline & $(0.002)$ & $(0.015)$ & $(0.000)$ & $(0.506)$ & $(0.003)$ & $(0.010)$ & $(0.007)$ & $(1.214)$ \\
\hline \multirow[t]{2}{*}{ education $_{\text {it }}$} & 0.000 & $-0.643 * * *$ & 0.000 & -0.919 & 0.000 & 0.000 & -0.008 & -2.166 \\
\hline & $(0.000)$ & $(0.068)$ & $(0.000)$ & $(0.962)$ & $(0.000)$ & $(0.000)$ & $(0.031)$ & $(4.673)$ \\
\hline \multirow[t]{2}{*}{ patent $_{i t}$} & $0.003 * * *$ & $-0.003 * * *$ & $0.001 *$ & 0.013 & $-0.003 * * *$ & $0.002 * * *$ & $0.004 * * *$ & -0.013 \\
\hline & $(0.000)$ & $(0.000)$ & $(0.000)$ & (0.009) & $(0.000)$ & $(0.000)$ & $(0.000)$ & $(0.029)$ \\
\hline \multirow[t]{2}{*}{$h t \_\exp _{i t}$} & $0.030 * * *$ & $0.072 * * *$ & -0.017 & -0.048 & $0.043 * * *$ & -0.003 & $0.104 * * *$ & 0.181 \\
\hline & $(0.002)$ & $(0.008)$ & $(0.010)$ & $(0.118)$ & $(0.003)$ & $(0.005)$ & $(0.007)$ & $(0.528)$ \\
\hline \multirow[t]{2}{*}{ budget $_{i t}$} & $0.025 * * *$ & -0.003 & $0.057 * * *$ & 0.382 & 0.000 & $-0.047 * * *$ & 0.000 & -0.021 \\
\hline & $(0.004)$ & $(0.020)$ & $(0.009)$ & $(0.430)$ & $(0.000)$ & $(0.010)$ & $(0.000)$ & $(1.244)$ \\
\hline \multirow[t]{2}{*}{$\beta_{o}$} & 0.000 & $5.607 * * *$ & 0.000 & 0.000 & 0.000 & 0.000 & 0.000 & 62.621 \\
\hline & $(0.000)$ & $(1.042)$ & $(0.000)$ & $(0.000)$ & $(0.000)$ & $(0.000)$ & $(0.000)$ & $(62.408)$ \\
\hline Observations & 446 & 402 & 402 & 401 & 446 & 402 & 402 & 401 \\
\hline $\begin{array}{l}\text { Number of } \\
\text { countries }\end{array}$ & 41 & 38 & 38 & 38 & 41 & 38 & 38 & 38 \\
\hline $\mathrm{AR}(1)$ test & 0.128 & 0.318 & 0.367 & 0.268 & & 0.174 & 0.000 & 0.440 \\
\hline $\mathrm{AR}(2)$ test & 0.370 & 0.709 & 0.566 & 0.785 & & 0.517 & 0.751 & 0.435 \\
\hline Sargan test & 0.995 & 0.688 & 0.249 & 1.000 & 0.967 & 0.656 & 0.287 & 0.997 \\
\hline KMO & 0.935 & 0.911 & 0.915 & 0.914 & 0.926 & 0.908 & 0.914 & 0.912 \\
\hline
\end{tabular}

Coefficients and standard errors estimated through two-step system GMM. Standard errors in parentheses. $* * * \mathrm{p}<0.01, * *$ $\mathrm{p}<0.05, * \mathrm{p}<0.1$. All regressions include time dummies, but their coefficients are not shown for presentation purposes. AR(1), AR(2) and Sargan are the first and second order autocorrelation test and the Sargan overidentification tests, respectively. KMO is the Kaiser-Meyer-Olkin measure of sampling adequacy used to assess the principal components analysis to reduce instruments.

The first four columns inform the results for the expenditure decentralization analysis. We find evidence that this type of decentralization leads to a reduction of government spending on basic research of around 0.02 percentage points (p.p.) per additional point of decentralization. As a consequence, the composition of the public innovation bundle changes, and the intensity of basic research decreases by 0.6 p.p. According to our estimates, expenditure decentralization also negatively affects the share of overall 
R\&D in government spending, with a magnitude of 0.03 p.p. (per additional decentralization point). On the other hand, no evidence of impact on 'applied research and development' spending was found. These results are statistically significant at a $95 \%$ confidence level.

Revenue decentralization estimates are displayed in the last four columns of Table 3 . We do not find evidence of modification in the composition of public innovation investment, but, on the other hand, its level is negatively affected by a higher scale than for the case of expenditure decentralization. The share of both basic research and 'applied research and development' in the public budget falls 0.07 p.p. and 0.04 p.p. as revenue becomes more decentralized by one percentage point, leading to an overall decrease of the R\&D spending share of 0.07 p.p. All results are significant even at a 99\% confidence level.

The coefficient for decentralization imbalance is statistically significant in almost all estimates where the fiscal decentralization parameter is also significant. This confirms that both revenue and expenditure decentralization should be considered when assessing their effect on government budget. The results support our choice of introducing an imbalance variable to consider both types of decentralization, solving the problem of high collinearity between them.

The control variables related to economic and demographic features in general present the expected sign and are significant explanatory variables. GDP is positively correlated with a higher intensity of R\&D in the public budget, raising the share of both basic and applied research. Trade openness suggests an increased spending on applied $R \& D$, while high-technology exports indicate higher levels of public basic research.

\subsection{Discussion of the Main Findings and Policy Implications}

The results of the empirical study confirm and provide evidence in favor of the two propositions that constitute the main conclusions of the theoretical model. We find evidence that expenditure decentralization affects the composition of the R\&D bundle, resulting in a lower share of basic research. In light of the literature on innovation spillovers, we argue that this result is mainly caused by higher levels of interregional externalities of basic research. As detailed in the model, subnational levels of government tend to invest less in this activity, as it is closer to a case of a global public good, with a high share of spillovers flowing to other regions. Governments at the national level, on the other hand, do not differentiate between such externalities and localized results, since they both affect national output, regardless of where the research takes place.

The empirical analysis also presents evidence that total government spending on innovation is negatively impacted by decentralization. The effect is stronger in the case of revenue decentralization, and we interpret this as a consequence of the higher influence of regional governments to set tax rates and determine government size. Although the theoretical model does not predict such outcome unambiguously, it is the most likely result, as expressed in Proposition \#2. The theoretical model explains the economic drivers of this result: interregional spillovers reduce the incentives for state governments to invest in $R \& D$ (in comparison with the central government), and these externalities are likely to overcome any positive effect in public innovation spending caused by state competition.

This result is at odds with the 'race to the top' hypothesis of the literature on fiscal decentralization and composition of public budget discussed in section 2.3. Our study suggests that the incentives of regional governments to spend more on productive activities to attract capital (Grisorio \& Prota, 2015; Sacchi \& Salotti, 2016) can be offset by considerable levels of interregional spillovers in the case of ST\&I activities. We also contribute to this literature by presenting both a theoretical argument and empirical evidence on the effects of decentralization on public innovation spending and its composition, a category that has not been assessed in previous analyses.

This study also contributes to the innovation policy literature discussed in section 2 . The negative impact of fiscal decentralization is in accordance with the evidence that innovation presents high levels of spillovers that are not geographically bounded (Bernstein \& Nadiri, 1989; Bloom et al., 2013; Mansfield et al., 1977; Wieser, 2005), and that basic research yields more results that are not internalized within regions (Funk, 2002).

Two main relevant policy implications can be derived from our findings. First, deepening fiscal decentralization should be considered along with measures to compensate for innovation spending 
decrease. Our estimates suggest that this reduction can be significant, and it provides a first assessment of its magnitude to be considered for policy analysis. The literature indicates different paths to address this problem, including a system of taxes and subsidies to compensate public R\&D investment at the state level (Oates, 2008a), and Coase-type bargaining between provinces (Hulten \& Schwab, 1997), although a cooperative arrangement may not be feasible because of transaction costs and opportunistic behavior.

The second main implication refers to the roles and responsibilities of different levels of government in the design of national strategies for ST\&I, or, considering a Schumpeterian perspective, the structure of national systems of innovation (Freeman, 1995). Division of functions is a topic particularly emphasized by the fiscal decentralization literature, as one can see from the decentralization theorem (Oates, 1972). This study suggests that, in light of different levels of interregional spillovers, the responsibility to finance or carry out basic research should be higher for central levels of governments, leaving state authorities with the role of promoting more applied research and development.

\section{Concluding remarks and further research agenda}

This paper analyses the relation between fiscal decentralization and public R\&D spending. It contributes to the existing literature by explaining how decentralization affects the size and composition of public innovation investment. We present a simple model of a closed economy where states compete for capital investment and public innovation spending improves production technology locally, but part of its results flow to other regions. Based on this theoretical framework, we show that interregional spillovers lead decentralized governments to dedicate a smaller share of their budget to basic research. The effect of decentralization on the size of spending is ambiguous because of state competition, but negative in most cases.

We test the conclusions of the model through an original empirical analysis with aggregate data. We present evidence that expenditure decentralization leads to a lower intensity of basic research in public R\&D (an estimated reduction of 0.02 p.p. per each additional point of expenditure decentralization), and that both types of decentralization negatively affect R\&D spending, although the impact is greater for revenue $(0.07$ p.p.) than for expenditure $(0.03$ p.p.) decentralization.

The main limitation of this study is the reduced availability of data on public innovation spending, limiting the number of observations that can be used in the quantitative empirical analysis. Nonetheless, this paper opens a promising research agenda on the links between fiscal decentralization and innovation policy. As more data on this topic becomes available, future studies can improve the empirical analysis, besides considering other variables and theoretical arguments.

In addition, relaxing some of the assumptions of our theoretical model can lead to different outcomes and insights for innovation policy design. Government decisions should change in case provinces have different sizes and levels of development. Also, following the original argument of the fiscal decentralization theorem, states can have different industrial sectors that require customized policies that are not efficiently implemented by a central government, an approach that should uplift the positive outcomes of decentralization for innovation.

\section{References}

Aghion, P., \& Howitt, P. (1992). A Model of Growth Through Creative Destruction. Econometrica, 60(2), 323-351. doi:10.2307/2951599

Aghion, P., \& Howitt, P. (1996). Research and development in the growth process. Journal of Economic Growth, 1(1), 49-73.

Aghion, P., \& Howitt, P. (1998). Endogenous growth theory: MIT press.

Akcigit, U., Hanley, D., \& Serrano-Velarde, N. (2013). Back to basics: Basic research spillovers, innovation policy and growth. Retrieved from

Alegre, J. G. (2010). Decentralization and the composition of public expenditure in Spain. Regional Studies, 44(8), 1067-1083. 
Arellano, M., \& Bond, S. (1991). Some tests of specification for panel data: Monte Carlo evidence and an application to employment equations. The Review of Economic Studies, 58(2), 277-297.

Arellano, M., \& Bover, O. (1995). Another look at the instrumental variable estimation of error-components models. Journal of econometrics, 68(1), 29-51.

Arrow, K. (1962). Economic welfare and the allocation of resources for invention. In The rate and direction of inventive activity: Economic and social factors (pp. 609-626): Princeton University Press.

Ashworth, J., Galli, E., \& Padovano, F. (2009). Government Decentralization and Public Spending Programs. Italian Society of Public Economics. In.

Audretsch, D. B., \& Feldman, M. P. (1996). R\&D spillovers and the geography of innovation and production. The American economic review, 86(3), 630-640.

Auerswald, P. E., Branscomb, L. M., Demos, N., \& Min, B. K. (2003). Understanding private-sector decision making for early-stage technology development. NIST Advanced Technology Program. NIST GCR.

Bernstein, J. I., \& Nadiri, M. I. (1989). Research and development and intra-industry spillovers: an empirical application of dynamic duality. The Review of Economic Studies, 56(2), 249-267.

Besley, T., \& Coate, S. (2003). Centralized versus decentralized provision of local public goods: a political economy approach. Journal of public economics, 87(12), 2611-2637.

Bloom, N., Schankerman, M., \& Van Reenen, J. (2013). Identifying technology spillovers and product market rivalry. Econometrica, 81(4), 1347-1393.

Blundell, R., \& Bond, S. (1998). Initial conditions and moment restrictions in dynamic panel data models. Journal of econometrics, 87(1), 115-143.

Brennan, G., \& Buchanan, J. M. (1980). The power to tax: Analytic foundations of a fiscal constitution: Cambridge University Press.

Busemeyer, M. R. (2007). Determinants of public education spending in 21 OECD democracies, 1980 2001. Journal of European Public Policy, 14(4), 582-610.

Chu, A. C., \& Furukawa, Y. (2013). Patentability and knowledge spillovers of basic R\&D. Southern Economic Journal, 79(4), 928-945.

Coe, D. T., \& Helpman, E. (1995). International r\&d spillovers. European Economic Review, 39(5), 859887.

Coe, D. T., Helpman, E., \& Hoffmaister, A. W. (2009). International R\&D spillovers and institutions. European Economic Review, 53(7), 723-741.

Cozzi, G., \& Galli, S. (2009). Science-based R\&D in Schumpeterian Growth. Scottish Journal of Political Economy, 56(4), 474-491.

Cruz, C., Keefer, P., \& Scartascini, C. (2016). The Database of Political Institutions 2015 (DPI 2015) In.

Dhillon, A., Wooders, M., \& Zissimos, B. (2007). Tax competition reconsidered. Journal of Public Economic Theory, 9(3), 391-423.

Diaz-Cayeros, A., McElwain, K. M., Romero, V., \& Siewierski, K. A. (2002). Fiscal Decentralization, and Particularistic Spending across Countries. Paper presented at the Conference on "Comparative Analysis of Political Institutions", Princeton University, Princeton, NJ, USA.

Edler, J., Cunningham, P., Gök, A., \& Shapira, P. (2013). Impacts of innovation policy: synthesis and conclusions. Compendium of Evidence on the Effectiveness of Innovation Policy Intervention Project) Manchester.

Edler, J., \& Fagerberg, J. (2017). Innovation policy: what, why, and how. Oxford Review of Economic Policy, 33(1), 2-23.

Eyraud, L., \& Lusinyan, L. (2013). Vertical fiscal imbalances and fiscal performance in advanced economies. Journal of Monetary Economics, 60(5), 571-587.

Fagerberg, J. (2017). Innovation policy: Rationales, lessons and challenges. Journal of Economic Surveys, $31(2), 497-512$.

Faguet, J.-P. (2004). Does decentralization increase government responsiveness to local needs?: Evidence from Bolivia. Journal of public economics, 88(3), 867-893.

Feidler, J., \& Staal, K. (2012). Centralized and decentralized provision of public goods. Economics of Governance, 13(1), 73-93. 
Fiva, J. H. (2005). New evidence on fiscal decentralization and the size of government.

Freeman, C. (1995). The 'National System of Innovation'in historical perspective. Cambridge Journal of economics, 19(1), 5-24.

Funk, M. (2002). Basic research and international spillovers. International Review of Applied Economics, $16(2), 217-226$.

Furman, J. L., Kyle, M. K., Cockburn, I. M., \& Henderson, R. (2006). Public \& private spillovers, location and the productivity of pharmaceutical research. Retrieved from

Granado, F. J. A. d., Martinez-Vazquez, J., \& McNab, R. (2005). Fiscal decentralization and the functional composition of public expenditures. Retrieved from

Griliches, Z. (1985). Productivity, R\&D, and basic research at the firm level in the 1970s. In: National Bureau of Economic Research Cambridge, Mass., USA.

Grisorio, M. J., \& Prota, F. (2015). The short and the long run relationship between fiscal decentralization and public expenditure composition in Italy. Economics Letters, 130, 113-116.

Hall, B. H., Mairesse, J., \& Mohnen, P. (2010). Measuring the Returns to R\&D. Handbook of the Economics of Innovation, 2, 1033-1082.

Hulten, C. R., \& Schwab, R. M. (1997). A fiscal federalism approach to infrastructure policy. Regional Science and Urban Economics, 27(2), 139-159.

IMF, I. M. F. (2014). Government finance statistics manual 2014. In. Washington, D.C.: International Monetary Fund.

IMF, I. M. F. (n.d.). IMF Government Finance Statistics. Retrieved from: http://data.imf.org/?sk=a0867067-d23c-4ebc-ad23-d3b015045405

Jaffe, A. B., Trajtenberg, M., \& Henderson, R. (1993). Geographic localization of knowledge spillovers as evidenced by patent citations. the Quarterly journal of Economics, 108(3), 577-598.

JEC, J. E. C. o. t. C. o. t. U. S. (2010). The 2010 Joint Economic Report. Retrieved from Washington DC.: https:/www.jec.senate.gov/public/_cache/files/1f859d11-f43b-4dd6-9f8b-a90199b02841/2010joint-economic-committee-annual-report.pdf

Jia, J., Guo, Q., \& Zhang, J. (2014). Fiscal decentralization and local expenditure policy in China. China Economic Review, 28(C), 107-122.

Kappeler, A., \& Välilä, T. (2008). Fiscal federalism and the composition of public investment in Europe. European Journal of Political Economy, 24(3), 562-570.

Katz, J. S. (1994). Geographical proximity and scientific collaboration. Scientometrics, 31(1), 31-43.

Keen, M., \& Marchand, M. (1997). Fiscal competition and the pattern of public spending. Journal of public economics, 66(1), 33-53.

Köhler, C., Laredo, P., \& Rammer, C. (2012). The impact and effectiveness of fiscal incentives for R\&D. Compendium of Evidence on the effectiveness of Innovation Policy.

Lichtenberg, F. R., \& Siegel, D. (1991). The impact of R\&D investment on productivity-New evidence using linked R\&D-LRD data. Economic Inquiry, 29(2), 203-229.

Malerba, F., Mancusi, M. L., \& Montobbio, F. (2013). Innovation, international R\&D spillovers and the sectoral heterogeneity of knowledge flows. Review of World Economics, 149(4), 697-722.

Mancusi, M. L. (2008). International spillovers and absorptive capacity: A cross-country cross-sector analysis based on patents and citations. Journal of International Economics, 76(2), 155-165.

Mansfield, E. (1980). Basic research and productivity increase in manufacturing. The American economic review, 70(5), 863-873.

Mansfield, E. (1991). Academic research and industrial innovation. Research Policy, 20(1), 1-12.

Mansfield, E., \& Lee, J.-Y. (1996). The modern university: contributor to industrial innovation and recipient of industrial R\&D support. Research Policy, 25(7), 1047-1058.

Mansfield, E., Rapoport, J., Romeo, A., Wagner, S., \& Beardsley, G. (1977). Social and Private Rates of Return from Industrial Innovations. the Quarterly journal of Economics, 91(2), 221-240.

Martinez-Vazquez, J., Lago-Peñas, S., \& Sacchi, A. (2017). The impact of fiscal decentralization: A survey. Journal of Economic Surveys, 31(4), 1095-1129.

Maurseth, P. B., \& Verspagen, B. (2002). Knowledge spillovers in Europe: a patent citations analysis. The Scandinavian journal of economics, 104(4), 531-545. 
Mehrhoff, J. (2009). A solution to the problem of too many instruments in dynamic panel data GMM.

Morales, M. F. (2004). Research policy and endogenous growth. Spanish Economic Review, 6(3), 179-209.

Nelson, R. R. (1959). The simple economics of basic scientific research. Journal of Political Economy, 67(3), 297-306.

Oates, W. E. (1972). Fiscal Federalism New York. Har-court Brace Jovanovich.

Oates, W. E. (1999). An essay on fiscal federalism. Journal of economic literature, 37(3), 1120-1149.

Oates, W. E. (2008a). On the evolution of fiscal federalism: theory and institutions. National Tax Journal, 61(2), 313-334.

Oates, W. E. (2008b). On the theory and practice of fiscal decentralization. Institutional foundations of public finance: Economic and legal perspectives, 165, 176.

Oates, W. E., \& Schwab, R. M. (1988). Economic competition among jurisdictions: efficiency enhancing or distortion inducing? Journal of public economics, 35(3), 333-354.

OECD. (2014). OECD Science, Technology and Industry Outlook 2014: OECD Publishing.

OECD. (2015). The Measurement of Scientific, Technological and Innovation Activities Frascati Manual 2015 Guidelines for Collecting and Reporting Data on Research and Experimental Development: Guidelines for Collecting and Reporting Data on Research and Experimental Development: OECD Publishing.

OECD. (2016). Fiscal Federalism 2016: Making Decentralization Work. Paris: OECD Publishing.

Park, W. G. (1998). A theoretical model of government research and growth. Journal of Economic Behavior \& Organization, 34(1), 69-85.

Peri, G. (2005). Determinants of knowledge flows and their effect on innovation. The review of Economics and Statistics, 87(2), 308-322.

Ponce-Rodriguez, R., Hankla, C. R., Martinez-Vazquez, J., \& Heredia-Ortiz, E. (2012). Rethinking the political economy of decentralization: how elections and parties shape the provision of local public goods.

Romer, P. M. (1990). Endogenous Technological Change. Journal of Political Economy, 98(5), S71-S102. doi:10.1086/261725

Roodman, D. (2006). How to do xtabond2: An introduction to difference and system GMM in Stata.

Sacchi, A., \& Salotti, S. (2016). A comprehensive analysis of expenditure decentralization and of the composition of local public spending. Regional Studies, 50(1), 93-109.

Salter, A. J., \& Martin, B. R. (2001). The economic benefits of publicly funded basic research: a critical review. Research Policy, 30(3), 509-532.

Shapiro, S., \& Taylor, J. (2013). Federal R \& D: Analyzing the Shift From Basic and Applied Research Toward Development. Honors Thesis 2013, Retrieved from http://economics.stanford.edu/files/Theses/SamShapiroHonorsThesis-May2013.pdf

Sinn, H.-W. (2003). The New Systems Competition, Yrjo Jahnsson Lectures, Helsinki 1999. In: Blackwell Publishing, Oxford.

Verspagen, B. (1992). Endogenous innovation in neoclassical growth models: a survey. Journal of Macroeconomics, 14(4), 631-662.

Verspagen, B., \& De Loo, I. (1999). Technology spillovers between sectors. Technological Forecasting and Social Change, 60(3), 215-235.

WB, W. B. (2017). World Development Indicators. Retrieved from: https://data.worldbank.org/indicator

Wieser, R. (2005). Research and development productivity and spillovers: empirical evidence at the firm level. Journal of Economic Surveys, 19(4), 587-621.

Young, A. (1992). A tale of two cities: factor accumulation and technical change in Hong Kong and Singapore. NBER macroeconomics annual, 7, 13-54.

Zodrow, G. R., \& Mieszkowski, P. (1986). Pigou, Tiebout, property taxation, and the underprovision of local public goods. Journal of urban economics, 19(3), 356-370. 